\title{
Effects of magnesium pemoline on shock avoidance conditioning and on various chemical measures'
}

\begin{abstract}
JOIN GAITO, JAMES H. DAVISON, and JAMES MOTTIN. York University and Waterloo University. Toronto, Ontario, Canada
\end{abstract}

Rats fed magnesium pemoline showed enhanced conditioning and decreased RNA and protein synthesis.

Rescarchers at Abbotts Laboratories have reported that magnesium pemoline enhances learning in a shock avoidance task and increases RNA polymerase activity (Glasky \& Simon, 1960; Plotnikoff, 1966). If magnesium pemoline enhances learning by stimulating RNA polymerase activity, it might result in increased RNA and protein synthesis throughout the entire brain or only in specific areas which are directly involved in the learning activity. The present experiments were concerned with the effects of magnesium pemoline on shock avoidance behavior and on the chemistry of specific brain sites.

\section{METHOD}

A one-way active avoidance conditioning task was used in three experiments with the shock level set at $2.5 \mathrm{~mA}$. Eight to 10 littermates (Wistar strain) were used in each experiment. All litters but seven were males. Their ages varied from 50 to 125 days but within each experiment the ages were similar.

Experimental (E) and Control (C) rats were food deprived for 24 to $28 \mathrm{~h}$. Both $E$ and $C$ animals received a small pellet of Purina Chow $2 \frac{1}{4} \mathrm{~h}$ before being sacrificed. The pellet was crushed in a small dish, moistened with $2 \mathrm{ml}$ of water, and placed in the cage with $E$ and $C$. $E$ rats received magnesium pemoline powder $(20 \mathrm{mg} / \mathrm{kg}$ of weight), well mixed within the crushed pellet. The $2 \frac{1}{4}-\mathrm{h}$ period was chosen because the Abbott Laboratories research had indicated that RNA polymerase activity was greatest at $2 \mathrm{~h}$.

Each rat was placed in the conditioning apparatus $13 / 4 \mathrm{~h}$ after feeding, allowed $15 \mathrm{~min}$ to adapt, and given 15 trials in $15 \mathrm{~min}$. At the end of the $30-\mathrm{min}$ period in the apparatus, each rat was sacrificed by immersion in liculid nitrogen for $10 \mathrm{sec}$. The brain was rapidly removed and sectioned in 10 parts as in previous experiments (Gaito, Mottin. \& Davison, in press): anterior ventral cortex (AV), medial ventral cortex (MV), posterior ventral cortex (PV), anterior dorsal cortex (AD), medial dorsal cortex (MD), posterior dorsal cortex (PD), cerebral hemispheres $(\mathrm{CH})$, cerebellum $(\mathrm{CB})$, upper brain stem (UBS), and lower brain stem (LBS) (sectioned just below the inferior colliculi). RNA, DNA, and proteins were extracted by a modified Schmidt-Thannhauser procedure and the amounts of each were determined by spectrophotometric analysis. In Experiment 2 each rat was injected intracranially with $5 \mu \mathrm{c}$ of orotic acid-6-C ${ }^{14}$ (precursor of RNA: specific activity -34.7 $\mathrm{mc} / \mathrm{mm}$ ) and in Experiment 3 with $5 \mu \mathrm{c}$ of valine-C ${ }^{4}$ (precursor of protein; specific activity-117 $\mathrm{mc} / \mathrm{mM}$ ) to determine incorporation rates into RNA and protein, respectively.

\section{Behavioral Measures}

\section{RESULTS}

Number of avoidances in 15 trials, latency of respense, and the trial of first avoidance were the dependent variables. The results for the three experiments were combined; there were 28 pairs of $\mathbf{E}$ and $\mathrm{C}$ rats. A Littermates by Treatments analysis of variance design indicated that the $E$ animals showed a significantly greater mean number of avoidances $(\mathrm{E}$ mean, 10.8: $\mathrm{C}$ mean, 8.6) than the $\mathrm{C}$ rats $(F=15.43 ; \mathrm{p}<.001)$. The latency data showed superiority for the $E$ animals ( $E$ mean,
3.4; $C$ mean, 4.0; $F=5.30 ; \quad p<.051$. There were no differences for the trial of first avoidance data.

Neurochemical Measures

The dependent variables were: Expcriment $1-$ RNA. DNA. and protein (all per gram of tissue, wet weight), RNA/DNA. prot/DNA, and prot/RNA: Experiment 2-relative specific activity of the RNA fraction (R.S.A. RNA), i.e., specitic activity of the RNA fraction/specific activity of the cell pool fraction; Experiment 3-relative specific activity of the protein fraction (R.S.A. Prot). i.e.. specific activity of the protein fraction/specific activity of the cell pool fraction. In Experiment 3, RNA, DNA, protein and the ratios were obtained but were combined with those in Experiment 1 for one analysis. Littemates by Conditions analyses of variance were conducted with the rejection region set at a $p$ of .10 so as to decrease Type II errors. Because Type I errors increase in this case, only results which were signiticant in two or more chemical measures and/or experiments were considered real ones.

Of the 10 tissues and six dependent variables (RNA, DNA. protein, and ratios of these), only $(B$ showed significant differences at $p \leqslant .10$ in DNA $(E>C)$. No significant differences between $E$ and $C$ appeared in R.S.A. RNA for any tissue in Experiment 2. However, for the specific activity of the RNA and cell pool fractions there was a tendency for the mean $E$ values to be less than those for $C$. For the former. $\mathrm{E}<\mathrm{C}$ in seven of the 10 tissues: in the latter. $\mathrm{E}<\mathrm{C}$ in eight of the tissues. In Experiment 3 there were significant results in R.S.A. Prot in PV and MV (in both, E< (). Also over the 10 tissues there was a tendency for $E$ rats to show a lower mean than $C$ animals in the specific activity of both protein and cell pood fractions. In Experiments 2 and 3 . higher mean values for relative specific activity occurred in the ventral cortical tissue than in other brain areas. ${ }^{2}$

\section{DISCUSSION}

The behavioral results are consistent with those of Plotnikoff (1966); magnesium pemoline seems to have a facilitatory effect on this type of leaning task with the species of rats used in this experiment. However, these experiments did not differentiate between performance and learning aspects; thus, the facilitation may be on performance and not directly on the learning process.

The neurochemical results are not consistent with those of Glasky \& Simon (1966); enhanced RNA synthesis did not occur. Instead a decreased amount of labelled precursor appeared in the cell pool, RNA, and protein fractions, suggesting decreased RNA and protein synthesis. But these experiments were conducted with animals in an active learning task whereas the Abbott research in which RNA polymerase activity was assessed did not utilize a behavioral task. The learning task can affect drastically the nucleic acids and proteins of tissue as indicated in previous experiments (Gaito. Mottin, \& Davison, in press) in which the sloock avoidance task produced a decremental effect on both RNA and protein synthesis with the high shock level used $(2.5 \mathrm{~mA})$ to effect quick learning. Yet in the present experiments both the $E$ and $C$ animals were involved in this task and received shock. Thus one would not expect that the $E$ rats would show lower values than Cs.

The significant differences for R.S.A. Prot in MV and PV tissues may be Type I errors or may suggest their involvement in this learning task. The significance of $M V$, and occasionally $P V$, in shock avoidance conditioning has been indicated in 
previous experiments. Further research is under way to evaluate the possibility that these tissues contribute uniquely to conditioning behavior. PEFERENCES

GAITO, J., MOTTIN, J., \& DAVISON, J. H. Chemical variation in brain loci during shock avoidance. Psychonomic Science, in press.

GLASKY, A. J., \& SIMON, L. N. Magnesium pemoline: enhancement of brain RNA polymerases. Science, 1966, 151, 702-703.
PLOTNIKOFF, N. Magnesium pemoline: Enhencement of learning and memory of a conditioned avoidance response. Soience, 1966, 151, 703-704.

NOTES

1. This work was supported by Office of Naval Research Contract Nonr-4935(00) and grants from the National Research Council of Canada.

2. Complete data may be obtained by writing the first author. 